\title{
The significance of interferon- $\gamma$ in HIV-1 pathogenesis, therapy, and prophylaxis
}

\author{
Shannon R. Roff, Ezra N. Noon-Song and Janet K. Yamamoto* \\ Department of Infectious Diseases and Pathology, College of Veterinary Medicine, University of Florida, Gainesville, FL, USA
}

Edited by:

Howard M. Johnson, University of

Florida, USA

\section{Reviewed by:}

So-Yon Lim, Harvard Medical School, USA

Michael Murphey-Corb, University of Pittsburgh School of Medicine, USA

\section{*Correspondence:}

Janet K. Yamamoto, Department of Infectious Diseases and Pathology, College of Veterinary Medicine, University of Florida, P.O. Box 110880 , Gainesville, FL 32611, USA e-mail:yamamoto@ufl.edu
Interferon- $\gamma$ (IFN $\gamma$ ) plays various roles in the pathogenesis of HIV/AIDS. In an HIV-1 infected individual, the production of IFN $\gamma$ is detected as early as the acute phase and continually detected throughout the course of infection. Initially produced to clear the primary infection, IFN $\gamma$ together with other inflammatory cytokines are involved in establishing a chronic immune activation that exacerbates clinical diseases associated with AIDS. Unlike Type 1 IFNs, IFN $\gamma$ has no direct antiviral activity against HIV-1 in primary cultures, as supported by the in vivo findings of IFN $\gamma$ therapy in infected subjects. Results from both in vitro and ex vivo studies show that IFN $\gamma$ can instead enhance HIV-1 replication and its associated diseases, and therapies aimed at decreasing its production are under consideration. On the other hand, IFN $\gamma$ has been shown to enhance cytotoxic T lymphocytes and NK cell activities against HIV-1 infected cells. These activities are important in controlling HIV-1 replication in an individual and will most likely play a role in the prophylaxis of an effective vaccine against HIV-1. Additionally, IFN $\gamma$ has been used in combination with HIV-1 vaccine to augment antiviral immunity. Technological advancements have focused on using IFN $\gamma$ as a biological marker to analyze the type(s) of immunity generated by candidate HIV vaccines and the levels of immunity restored by anti-retroviral drug therapies or novel immunotherapies. Hence, in addition to its valuable ancillary role as a biological marker for the development of effective HIV-1 prophylactic and therapeutic strategies, IFN $\gamma$ has a vital role in promoting the pathogenesis of HIV.

Keywords: interferon- $\gamma$, HIV-1 pathogenesis, IFN $\gamma$ therapy, anti-retroviral therapy, HIV-1 vaccine

\section{INTERFERON- $\gamma$ IN THE PATHOGENESIS OF HIV-1}

Interferon- $\gamma($ IFN $\gamma)$ is a Type II interferon that is pivotal in the regulation of the host immune response against viral and intracellular bacterial pathogens. The effects of IFN $\gamma$ are broad and far-reaching, exhibiting polyfunctional effects on immune activation, proinflammatory responses, and immune modulation. High levels of IFN $\gamma$ are secreted by Type $1 \mathrm{~T}$ helper cells (Th1 cells), $\mathrm{CD}^{+}$cytotoxic $\mathrm{T}$ lymphocytes (CD8 ${ }^{+} \mathrm{CTLs}$ ), and NK cells during active infection (1). IFN $\gamma$ has a major effect on the regulation of antigen presentation by macrophages and dendritic cells, and in induction of class switching of B cells $(2,3)$. As a proinflammatory cytokine IFN $\gamma$ directly activates phagocytic cells and stimulates oxidative burst and the release of degradative enzymes, thereby supporting the host defense responses against intracellular pathogens (4). IFN $\gamma$ also induces the production of proinflammatory cytokines and chemokines on endothelial cells, epithelial cells, and fibroblasts. Focal release of IFN $\gamma$ results in vasodilation and upregulation of adhesion molecules, promoting diapedesis of neutrophils, and macrophages to the site of inflammation. In addition to upregulation of innate defense mechanisms, IFN $\gamma$ is also pivotal in immune modulation. Moreover, IFN $\gamma$ upregulates the expression of MHC-I and -II molecules, activates antigen presenting cells and induces macrophage maturation toward a proinflammatory phenotype $(4,5)$. IFN $\gamma$ also works synergistically with other cytokines such as IL-2 and - 4 to balance the Thelper subsets
Th1/Th2, regulating the cytotoxic versus humoral $\mathrm{T}$ cell immune response (6). It is this integral part in the immune regulation and proinflammatory antiviral response that has made IFN $\gamma$ an attractive biomarker to evaluate the immune competence and antiviral response in HIV-1 patients.

\section{IFN $\gamma$ EXPRESSION IN SERONEGATIVE INFANTS BREASTFED BY HIV-1 POSITIVE MOTHERS}

It is estimated that $20-45 \%$ of infants born to HIV positive mothers become HIV positive in the perinatal period $(7,8)$. Of these infants, $25-35 \%$ infected within the first year of life acquire the disease through breast feeding (7). Although this patient subset represents individuals with naïve and underdeveloped immune systems, multiple studies have demonstrated competent HIV-1 specific IFN $\gamma$ responses in infants $<1$ year of age $(7-11)$. Legrand et al. detected HIV-1 specific IFN $\gamma$ responses generated specifically from $\mathrm{CD}^{+} \mathrm{T}$ cell subsets, demonstrating the ability of this naïve immune system to develop an antigen-specific $\mathrm{T}$ cell response (11). In a Nairobi trial of more than 200 breast fed infants born to HIV-1 positive $\left(\mathrm{HIV}^{+}\right)$mothers, more than half of exposed infants remained seronegative for the first year of life (8). The IFN $\gamma$ response in these exposed but uninfected infants was significantly increased compared with infected cohorts, revealing a positive correlation of increased IFN $\gamma$ response with those infants that remained HIV-1 seronegative up to 1 year of age (Table 1) (8). 
Table 1 | Predictive value of IFN $\gamma$ expression.

\begin{tabular}{|c|c|c|c|c|}
\hline Disease status & Age & HIV-specific IFN $\gamma$ expression & Predictive value of IFN $\gamma$ expression & Reference \\
\hline Highly exposed, seronegative & $\begin{array}{l}\text { Breastfed } \\
\text { infant }\end{array}$ & Elevated, transient & Positive correlation with seronegative status & (8) \\
\hline Highly exposed, seronegative & Adult & Highly elevated & No correlation to rate of seroconversion & $(12)$ \\
\hline Infected & Infant & $\begin{array}{l}\text { Elevated, attenuated } \\
\text { compared to adults }\end{array}$ & No correlation with HIV load set points or mortality & $(7,8)$ \\
\hline Acute & Adult & Elevated & No correlation with HIV load set point or disease progression & $(13)$ \\
\hline Chronic, non-progressive & Adult & Persistently elevated & No correlation with stage or chronicity of clinical disease & $(14-16)$ \\
\hline Chronic, progressive & Adult & Persistently elevated & No correlation with stage or chronicity of clinical disease & $(14-16)$ \\
\hline
\end{tabular}

Although there was a significant increase in IFN $\gamma$ expression in the exposed/uninfected infants, IFN $\gamma$ levels were moderate and often cyclical to transient with only $12-22 \%$ of them having detectable IFN $\gamma$ at any given time point (8). This suggests that prolonged, repeated exposure to HIV-1 through breast feeding was a significant factor in inducing and maintaining an IFN $\gamma$ response (8, 9). Highly exposed, persistently seronegative sex workers demonstrate high levels of HIV-1 specific IFN $\gamma$ responses in CD8 ${ }^{+}$CTLs (Table 1) (12). Individuals within this cohort who had a 2-month or greater break in sex work were 6.5 times more likely to seroconvert, suggesting a significant decrease in HIV-1 antigen-specific response resulting from a gap in prolonged and repeated antigen exposure (12).

\section{IFN $\gamma$ EXPRESSION IN HIV-1 INFECTED NEONATES AND INFANTS}

Although the naïve state of the neonatal and infant immune system is a concern in HIV-1 exposure, HIV-1 specific CTL responses have been reported in both exposed and infected infants $(7,8,10,11)$. HIV-1 infected infants $<1$ year of age with a detectable circulating viral load mount a substantial and sustained antigen-specific immune response. However, the magnitude of their response is attenuated as compared with adults (8). It is theorized that this attenuated response in infected infants may be attributed to an overall decrease in IFN $\gamma$ producing cells, a suppression of the Th1 response, underdevelopment of the $\mathrm{CD} 4^{+} \mathrm{T}$ cell repertoire, or immaturity of antigen processing related to age (10). Although a reduction of the number of IFN $\gamma$ producing cells correlates with a decrease in the overall $\mathrm{CD} 4^{+}$counts in infected infants a twofold increase in $\mathrm{HIV}-1$ specific IFN $\gamma$ response was detected in infected infants in the first year of life (10). This increase not only demonstrates a continued expression of IFN $\gamma$ in infected infants, but also showed a significant trend toward an increased immunologic response when limited to those breastfed infants surviving 1 year or more (10). Even though an increased IFN $\gamma$ response and HIV-1 specific CTL can be detected in HIV-1 infected infants, there is no correlation between the presence of antigen-specific CTL or IFN $\gamma$ response to reduction in peak viral load, viral steady state, or incidence of mortality in infected infants (Table 1) (10). Therefore, this positive trend likely reflects the immunologic stimulation attributed to continued and prolonged exposure to HIV-1 rather than a sustained response to initial infection.

\section{IFN $\gamma$ EXPRESSION IN ACUTE AND CHRONIC HIV-1 INFECTION}

Throughout the acute stage of HIV-1 infection, IFN $\gamma$ levels in infected adults steadily increase, with a peak approximately 20 24 days post-infection (Table 1) (13). In chronic, stable disease, IFN $\gamma$ levels decline to a steady state that is often equivalent to healthy controls (17). Although there is a predictable elevated trend in overall IFN $\gamma$ expression during HIV-1 clinical disease, no significant difference has been reported in HIV-1 specific IFN $\gamma$ response of the CTLs in both progressor and long-term nonprogressor patients with chronic disease (17). Although overall expression of IFN $\gamma$ by $\mathrm{CD} 8^{+}$CTLs does not correlate to stage or chronicity of clinical disease, significantly larger numbers of HIV-1 specific CTLs are maintained in long-term non-progressors $(18,19)$. There is a significant trend of steady increase of IFN $\gamma$ levels in chronic, progressive disease however, there is marked patient to patient variability in overall expression of IFN $\gamma$ with no demonstrable correlation between IFN $\gamma$ expression and viral load, viral set point, viral clearance, or chronicity (14-16) (Table 1). In a cross-sectional study performed by Wantanabe et al. (20), proinflammatory cytokines TNF-alpha, IL-6, IL-10, IL-18, and IL7 levels had a significant correlation with CD4 count in $\mathrm{HIV}^{+}$ patients, but IFN $\gamma$ levels were often continuously elevated and variable between patients with no significant correlation to progressors and long-term non-progressors in chronically infected patients (20). Several theories exist as to why IFN $\gamma$ response does not correlate with disease progression and largely center on the polyfunctional and proinflammatory effects of IFN $\gamma$ (16). It has been suggested that cytokine expression and immunologic profiles in $\mathrm{HIV}^{+}$patients are more proinflammatory than immunoregulatory when compared to uninfected but exposed controls (21). It is also likely that HIV-1 infection results in modification of antigen presentation in macrophages and dendritic cell lines, resulting in anergy of HIV-1 specific CD4 ${ }^{+}$and $\mathrm{CD}^{+} \mathrm{T}$ cells (22). Another theory suggests diminished response to IFN $\gamma$ in target populations may alter immunomodulation of Th1/Th2 response through the production of synergistic (IL-2, TNF $\alpha$ ) or inhibitory (TGF $\beta$, IL10, IL-13) cytokines (16). A recent study evaluated a combined proinflammatory and immunomodulatory cytokine panel including IFN $\gamma$ to predict viral load set point 12 months after infection (23). In the combined panel, IFN $\gamma$, IL-12p40/70, IL-7, and IL-15 levels predicted $66 \%$ of viral set point variation in acute phase 
patients (23). Further studies are required to evaluate the predictive value of this panel on morbidity and progression of patients with chronic disease. In addition to the polyfunctional effects of IFN $\gamma$, and due to the marked complexity of the antiviral response, it is likely that monitoring of HIV-1 patients by a proinflammatory cytokine panel rather than relying on a single cytokine will better predict viral load set point and progression of clinical disease.

\section{IFN $\gamma$ IN THERAPY AGAINST HIV/AIDS}

Many studies have been performed to determine the roles that IFN $\gamma$ plays in anti-HIV therapy. Initially, clinical studies determined that IFN $\gamma$ can either hinder or augment the pathogenesis of HIV-1. The latter observations raised a major concern about the use of IFN $\gamma$ in HIV-1 therapy. Concomitantly, a number of in vitro studies tested the anti-HIV activity of IFN $\gamma$ on HIV-1 infection but with conflicting results. Subsequently, a small number of clinical trials investigated whether IFN $\gamma$ has therapeutic effects against HIV-1 in $\mathrm{HIV}^{+}$subjects. With the growing understanding of the roles that cytokines play in infection and disease progression, cytokines including IFN $\gamma$ have been measured to assess the efficacy of anti-retroviral therapy (ART). ART has greatly improved the quality of life and the lifespan of the HIV-infected subjects but does not substantially restore the immune system destroyed by HIV-1. Consequently, IFN $\gamma$ and cytokines which induce or enhance IFN $\gamma$ activity have been considered for therapy to restore the immune system in particular T cell number and function. The opposing or conflicting effects of IFN $\gamma$ on HIV-1 pathogenesis and immune function have complicated the role that IFN $\gamma$ plays on anti-HIV therapy.

\section{IFN ANTIVIRAL ACTIVITY}

Interferons were originally discovered, named, and characterized based on their ability to inhibit viral replication (24). These soluble factors are classified as Type I and II IFNs with IFN $\gamma$ being the sole representative of the Type II IFN family $(25,26)$. Although both Type I and II IFNs can induce an antiviral host response, they differ by both antigenic induction, receptor specificity, and cell expression. While Type I IFNs are largely induced by viral infection of host cells, IFN $\gamma$ is induced by more generalized antigenic and mitogenic stimulation (25). Type I IFNs are secreted at low levels by almost all cell types, however are primarily secreted by hematopoietic cells (IFN $\alpha$, IFN $\omega$ ) and fibroblasts (IFN $\beta$ ) (26). IFN $\gamma$ is primarily produced by $\mathrm{CD}^{+}{ }^{+}$and $\mathrm{CD} 8^{+} \mathrm{T}$ cells as well as NK cells with more recent reports of low level expression in NKT cell and professional antigen presenting cells (26). Both Type I and II IFNs induce a wide range of proteins with activity targeting different stages of viral replication. However, IFN $\gamma$ upregulates MHC-I on the cell surface, which increases antigenic recognition of intracellular pathogens by CTLs. In addition, only IFN $\gamma$ can upregulate the MHC-II pathway, supporting antigen-specific activation of $\mathrm{CD} 4^{+} \mathrm{T}$ cells $(25,26)$.

There are a number of IFN-induced proteins and gene products that confer antiviral activity. The first of these is dsRNA-regulated protein kinase (PKR) which is a serine/threonine kinase found predominantly in the cytoplasm and associated with ribosomes. PKR is activated by dsRNA and inhibits the synthesis of viral proteins through phosphorylation of eukaryotic translation initiation factor-2 (eIF-2). In addition to antiviral activity, PKR also plays a role in modulation of cell proliferation and induction of apoptosis $(25,26)$. The dsRNA-specific adenosine deaminase (ADAR), catalyzes the deamination of adenosine to inosine, resulting "editing" or mistranslation of the viral sequence. Mistranslation of gene products can lead to the production of non-functional viral proteins. The $2^{\prime}, 5^{\prime}$-oligoadenylate synthetase (OAS) in combination with RNase $\mathrm{L}$ is activated by dsRNA during viral infection and induces degradation of RNA. The protein Mx GTPases, a superfamily of dyamin-like GTPases, associate with viral protein complexes to impair transport of viral nucleocapsids into the nucleus of the host cell, preventing transcription. Type 1 IFN-regulated gene expression of Mx1 and CD317 may be involved in control of HIV neurovirulence (27). Although Mx GTPases are induced by Type I IFNs but not by Type II IFN $\gamma$ (25), other classes of GTPases are induced by IFN $\gamma$ allowing antiviral targeting of GTP by other mechanisms (26). More recent findings on IFN-induced tetherin/BST-2, an antagonist of HIV Vpr, may be important in prevention/control of HIV infection via innate immunity (28).

Several IFN-inducible mechanisms are involved in host response and immune evasion of HIV. The expression of HIV Trans-activator of transcription (Tat) can either negatively or positively affect IFN-induced PKR in regulating HIV-1 infection. Tat can prevent autophosphorylation of PKR and competes with eIF2 while upregulating NF- $\kappa \mathrm{B}$ to promote transcription (25). IFN response/regulatory factors (IRFs) compete with the binding site of HIV's LTR promoter and suppress viral transcription (29). Both Type I and II IFNs induce PKR, OAS, and ADAR, however there is a significant difference in the sensitivity to Type I and II IFNs to HIV in PBMC, T cells, and macrophages. Although the specific cause has not been elucidated, it is likely that the constant presence of IFN $\gamma$ will most likely promote negative regulation of IFN $\gamma$ signaling through the SOCS pathway (particularly SOCS1) and PIAS, a Stat inhibitor. Induction of these proteins target at various stages of viral replication and can induce an "antiviral state" within the host. However, adaptation and host evasion mechanisms allow replication of species adapted lentiviruses [HIV in humans, simian immunodeficiency virus (SIV) in macaques] despite the induction of IFN-induced anti-retroviral states (30).

\section{THE USE OF IFN $\gamma$ IN HIV/AIDS THERAPY}

The direct effect of IFN $\gamma$ on HIV-1 infection was first evaluated in in vitro studies followed by small scale clinical trials. In vitro studies have shown IFN $\gamma$ treatment to either enhance or have no effect on HIV-1 infection of PBMC (31). These observations with PBMC were strikingly different from what was expected in 1986 since all interferons $(\alpha, \beta, \gamma)$ were thought to have direct antiviral activities to all types of viruses (32). Subsequent, in vitro studies demonstrated that IFN $\gamma$ treatment can enhance HIV-1 infection in both primary macrophages and $\mathrm{CD}^{+}{ }^{+} \mathrm{T}$ cells (33-35), suggesting that these immune cell subsets were responsible for the original observation of HIV-1 infection of PBMC.

Given that IFN $\gamma$ is also produced early during cytokine storms in the acute stage of HIV-1 infection, IFN $\gamma$ was thought to affect the subsequent development of CTL activities to control HIV-1 load (36-38). There is a conflicting view regarding the role of cytokines such as IFN $\gamma$ in modulating cellular immunity which 
can in turn determine the viral set point $(38,39)$, as a high viral set point is positively associated with progression to AIDS (40, 41). The well documented role of IFN $\gamma$ in enhancing CTL activities against viral infection has supported the concept that IFN $\gamma$ therapy can augment anti-HIV CTL activities in $\mathrm{HIV}^{+}$subjects $(42,43)$. This is further supported by the finding that early control of HIV-1 load correlates with production of anti-HIV CD4 ${ }^{+}$ and $\mathrm{CD}^{+}{ }^{+}$CTLs $(36,37,44)$, while similar control of virus load has been described for $\mathrm{HIV}^{+}$long-term survivors (LTSs) (45), elite controllers (ECs) $(46,47)$, and highly exposed persistently seronegative women (48). Based on these observations, clinical trials in adult patients have evaluated the toxicity, pharmacokinetics, and therapeutic effect of IFN $\gamma$ on HIV-1 p24 load, AIDSassociated complex (ARC), and AIDS-associated Kaposi's sarcoma (KS) (49-52). The majority of the clinical trials showed no significant improvement in ARC or KS as well as no significant decrease in HIV-1 p24 load (Table 2) (49-52). IFN $\gamma$ had no effect at doses that conferred therapeutic efficacy for IFN $\alpha$ or even at higher doses that resulted in mild toxicity (53-57). Notably, in comparison to the potent anti-HIV and -KS activities of IFN $\alpha$ and $\beta$, the lack of anti-HIV/AIDS activities of IFN $\gamma$ greatly reduced the enthusiasm toward IFN $\gamma$ and therapeutic focus shifted to IFN $\alpha$ as therapy against HIV/AIDS (57). Although clinical trials have also been conducted with pegylated IFN $\alpha$ to modulate its activity, the general consensus is that IFN $\alpha$ therapy is too toxic and significantly less effective than ART in decreasing HIV-1 load but is effective for treatment of KS (58-60).

\section{IFN $\gamma$ LEVELS AT PRE- AND POST-ART}

Clinical assessment of IFN $\gamma$ levels in the serum of $\mathrm{HIV}^{+}$adult subjects at different clinical stages has been used to determine the importance of IFN $\gamma$ in the pathogenesis of HIV-1. Clinical studies have focused on the changes in cytokine levels upon introduction of highly active anti-retroviral therapy (HAART), or ART. The elevation of multifunctional cytokines such as IFN $\gamma$ and $\mathrm{TNF} \alpha$, can either enhance or control HIV-1 infection depending on the clinical stage of HIV-1 infection. A cross-sectional study showed significantly elevated serum levels of certain cytokines (TNF $\alpha$, IL-6, IL-7, IL-10, IL-18) and an increasing trend for serum
IFN $\gamma$ levels in symptomatic subjects when compared to asymptomatic subjects prior to treatment with ART (20). Cross sectional and longitudinal clinical studies, comparing pre-ART to post-ART subjects demonstrated high serum levels of many cytokines (IL6 , IL-10, IL-18) in pre-ART subjects which significantly decreased when ART was initiated. Concomitant with ART, the serum HIV-1 load decreased to low or undetectable levels while the $\mathrm{CD} 4{ }^{+}$counts and serum IL-21 often increased $(20,72-77)$. In the case of IFN $\gamma$, cross-sectional study of pre- and post-ART showed a decreasing trend in serum IFN $\gamma$ levels with the initiation of ART (Table 2) (20). In comparison, a longitudinal study showed a statistically significant decrease in IFN $\gamma$ after 60 days or longer on ART (20). Although the majority of the subjects had a major decrease in IFN $\gamma, 33 \%$ of the subjects maintained high serum IFN $\gamma$ levels. In this study, all $\mathrm{HIV}^{+}$subjects were treated for secondary clinical diseases before enrollment to ensure cytokine changes during the study were predominantly attributed to HIV-1 infection. Thus, the authors of this work speculated that sustained high IFN $\gamma$ levels in this group were due to individual differences in immune responses against HIV-1, the genetic characteristics of HIV-1, or both, and not due to other potentially confounding clinical events (20).

Another approach for evaluating the immune status at preand post-ART is to measure the level of IFN $\gamma$ responses to HIV-1 proteins or peptides by the PBMC or T cells from $\mathrm{HIV}^{+}$subjects $(78,79)$. The hallmark of HIV-1 infection is the loss of $\mathrm{CD}^{+}{ }^{+} \mathrm{CD} 4{ }^{+} \mathrm{T}$ cell counts correlating with increases in both virus load and disease progression (80). As a result, measuring $\mathrm{T}$ cell immunity, specifically $\mathrm{CD}^{+} \mathrm{CD} 4{ }^{+} \mathrm{T}$ cell activities, was thought to be useful at assessing the immune status of the $\mathrm{HIV}^{+}$subject when analyzed in combination with $\mathrm{CD} 3^{+} \mathrm{CD} 4^{+} \mathrm{T}$ cell count and virus load $(81,82)$. HIV-specific $\mathrm{CD} 3^{+} \mathrm{CD} 8^{+} \mathrm{T}$ cell activities develop shortly after the cytokine storm and work to control HIV-1 load during acute infection (37-39). Remarkably, IFN $\gamma$ responses were consistently detected in both $\mathrm{CD}^{+}{ }^{+} \mathrm{CD} 4^{+}$and $\mathrm{CD}^{+}{ }^{+} \mathrm{CD} 8{ }^{+} \mathrm{T}$ cells of the $\mathrm{HIV}^{+}$subjects at various clinical stages, but IFN $\gamma$ responses alone had no direct correlation to delay in progression to AIDS $(78,82-84)$. The presence of polyfunctional T cells, which expressed IFN $\gamma$ in combination with other cytokines (IL-2 and TNF $\alpha$ ) and/or cytotoxins (perforin or granzyme), was

Table 2 | Interferon- $\gamma$ in therapy against HIV/AIDS.

\begin{tabular}{|c|c|c|}
\hline Description $^{\mathrm{a}}$ & IFN $\gamma$ activity or response & Reference \\
\hline IFN $\gamma$ therapy against HIV/AIDS & No effect on HIV load, CD4 ${ }^{+} T$ cell count, and disease progression & $(53-57)$ \\
\hline Adjunctive IFN $\gamma$ therapy for opportunistic infection & Decreasing trend to significant decrease in opportunistic infection & $(61-67)$ \\
\hline \multicolumn{3}{|l|}{ IFN $\gamma$ levels during ART } \\
\hline \multicolumn{3}{|l|}{ Serum IFN $\gamma$ levels } \\
\hline Cross-sectional study & Decreasing trend in serum IFN $\gamma$ & $(20)$ \\
\hline Longitudinal study & Significant decrease in serum IFN $\gamma$ & $(20)$ \\
\hline \multicolumn{3}{|l|}{ T cell responses } \\
\hline $\mathrm{CD}^{+}+\mathrm{T}$ cells & Varying IFN $\gamma$ responses & $(68-70)$ \\
\hline $\mathrm{CD}^{+} \mathrm{T}$ cells & Generally decreasing IFN $\gamma$ response & $(70,71)$ \\
\hline Polyfunctional CD8+ T cells & Gradual increase in IFN $\gamma$ response with prolonged ART & $(71)$ \\
\hline
\end{tabular}

${ }^{a}$ Chronically HIV-1 infected subjects. 
associated with HIV-1 non-progression $(81-84) . \mathrm{CD}^{+}{ }^{+} \mathrm{CD} 4^{+}$and $\mathrm{CD} 3^{+} \mathrm{CD} 8^{+} \mathrm{T}$ cells induced with viral epitopes are important effector cells against HIV-1 infection. The IFN $\gamma$ analysis of T cells from chronically HIV-1 infected patients during ART demonstrated that HIV-specific IFN $\gamma$ responses varied within the T cell subsets evaluated $(68-71,85)$. Moreover, during ART, IFN $\gamma$ responses of HIV-specific $\mathrm{CD} 4^{+} \mathrm{T}$ cells expanded and contracted (68), decreased (69), or increased (70); while those of $\mathrm{CD}^{+} \mathrm{T}$ cells generally decreased $(70,71)$ (Table 2). Interestingly, HIV-specific IFN $\gamma$ responses of polyfunctional $\mathrm{CD}^{+} \mathrm{T}$ cells increased (85).

\section{IFN $\gamma$ AS AN ADJUNCTIVE CYTOKINE THERAPY}

The highly effective ART was released in developed countries in late 1990s (86) and in developing/underdeveloped countries in mid 2000 (87). ART is a combination of two or more anti-retroviral drugs that inhibits viral reverse transcriptase (RT) (nucleoside and non-nucleoside RT inhibitors), protease, integrase, viral coreceptor attachment (CCR5 inhibitor), and/or virus penetration (fusion inhibitor) (88). ART will decrease the circulating HIV1 load to low or undetectable levels in plasma within weeks to months (89). It has dramatically reduced the HIV-associated morbidity and mortality but the opportunistic infections and AIDS-associated cancers still persist despite ART (88). Moreover, even after 7-10 years of ART and viral control, a complete reconstitution of immune responses to HIV-1 has not been achieved while only a modest improvement in HIV-specific $\mathrm{T}$ cell responses was observed (90-92). Consequently, a rapid means to restore anti-HIV T cell immunity is still required.

Many therapy using cytokines (IL-2, IL-12, G-CSF, GM-CSF) including IFN $\gamma$ have been evaluated in combination with ART as immune reconstitution therapy (93-95). These therapies are needed due to the new-onset opportunistic infections resulting from failed ART combinations or simply due to the inability of ART to completely eliminate the opportunistic infection (96-98). In one study in South Africa, tuberculosis (TB) incidence rates during 8 years of follow-up showed substantially higher rates in $\mathrm{HIV}^{+}$subjects on long-term ART than in HIV uninfected individuals living in the same community (92). IFN $\gamma$ has been used as adjunctive immunotherapy with or without ART for the treatment of HIV-associated opportunistic infections such as cryptococcal meningitis (61-63), Pneumocystis carinii $(64,65)$, Toxoplasma gondii (65), Candida albicans (64, 65), Mycobacterium avium (65, $66)$, and visceral leishmaniasis $(65,67)$. In a majority of the cases, adjunctive IFN $\gamma$ therapy with or without other cytokines did not adversely affect the ART therapy for those on ART (i.e., maintained low to undetectable virus load) and did not increase $\mathrm{CD} 4^{+}$ $\mathrm{T}$ cell counts in most $\mathrm{HIV}^{+}$patients except for those ART (6166). These therapies had either a decreasing trend or a significant decrease in various HIV-associated opportunistic infections which were often resistant to conventional therapy against the organism (Table 2) (61-67).

Ten to $32 \%$ of AIDS patients starting ART develop an unusual disease condition called immune restoration disease (IRD) or immune reconstitution inflammatory syndrome (IRIS) (99-103). IRIS is a disease condition where the opportunistic infections or other diseases (e.g., Graves' disease, neoplasm, or virus-associated diseases) of the AIDS patients worsen shortly after the initiation of ART (99-101). The neoplasm and/or virus-associated diseases observed in IRIS included KS with human herpesvirus-8, nonHodgkin's lymphoma with Epstein-Barr virus, and progressive multifocal leukoencephalopathy with JC virus $(99,101)$. IFN $\gamma$ together with TNF $\alpha$, C-reactive protein, and IL-7 are the inflammatory cytokines all contribute to the development of IRIS (101103). As a result, anti-inflammatory therapy in addition to the anti-microbial therapy, is commonly used to treat IRIS associated with opportunistic infections (99).

\section{IFN $\gamma$ IN THE DEVELOPMENT OF AN EFFECTIVE HIV-1 VACCINE}

The development of an effective HIV-1 vaccine for humans requires the identification of protective HIV-1 vaccine epitopes conserved among most HIV-1 subtypes, the construction of protective epitopes into a vaccine immunogen, and determining the best vaccine delivery system for induction of both mucosal and systemic immunity against HIV-1. As the cytokines expressed by many T cell subsets, IFN $\gamma$ and IL-2 have been used as the biomarkers for $\mathrm{CD}^{+}$and $\mathrm{CD} 8^{+} \mathrm{T}$ cell activities induced by candidate HIV-1 vaccine antigens. Both of these cytokines are important in enhancing HIV-specific CTL activities and antibody synthesis essential for generating vaccine immunity. Ideally, cytokines produced by $\mathrm{CD} 3^{+} \mathrm{CD} 4^{+}$Th cells should augment effector functions of both $\mathrm{T}$ and $\mathrm{B}$ cells upon vaccination. Initial HIV-1 vaccine studies searched for B-cell epitopes on HIV-1 envelopes (transmembrane and surface envelopes) that induced broadly reactive virus neutralizing antibodies, while subsequent vaccine studies focused on developing an HIV-1 vaccine that induced potent antiHIV CTL activities. IFN $\gamma$ has had a major impact on determining the presence of $\mathrm{CD} 8^{+} \mathrm{CTL}$ epitopes on HIV-1 proteins, with the highest levels detected from HIV-1 Gag, Pol, and Nef proteins. In the most successful HIV-1 vaccine trial, both polyfunctional $\mathrm{CD} 4^{+} \mathrm{T}$ cells and $\mathrm{CD} 4^{+}$CTLs that expressed IFN $\gamma$ and other cytokines or cytotoxins were detected in the vaccinees. Thus far, IFN $\gamma$ has played a major role as a biomarker of $\mathrm{T}$ cell activation in the development of an HIV-1 vaccine.

\section{IFN $\gamma$ IN EVALUATING HIV VACCINE EPITOPES}

The IFN $\gamma$ responses to HIV-1 peptides by the PBMC or T cells from $\mathrm{HIV}^{+}$subjects have been used to identify the regions on the virus that induced $\mathrm{CD}^{+}{ }^{+} \mathrm{CD} 8{ }^{+} \mathrm{CTL}$ and $\mathrm{CD}^{+}{ }^{+} \mathrm{CD} 4^{+} \mathrm{T}$ cell activity (78). Three of the most commonly used assays for such analysis are tetramer staining, IFN $\gamma$ ELISpot analysis, and FACSbased intracellular staining (ICS) for IFN $\gamma$ in combination with $\mathrm{T}$ cell phenotypic markers $(16,78,104,105)$. Since the reagents for IFN $\gamma$ became available before other cytokines and cytotoxins, the latter two analyses frequently utilize IFN $\gamma$. Furthermore, IFN $\gamma$ responses of T cells are detected throughout the duration of HIV-1 infection $(78,106)$. IFN $\gamma$ ELISpot is a more rapid and cost efficient assay than ICS or tetramer analyses. The IFN $\gamma$ ELISpot analysis using purified $\mathrm{CD}^{+}{ }^{+} \mathrm{CD} 8^{+}$and $\mathrm{CD} 3^{+} \mathrm{CD} 4^{+} \mathrm{T}$ cells was initially used to map the $\mathrm{CD} 8^{+}$CTL and $\mathrm{CD} 4^{+}$Th epitopes on HIV-1 proteins. Some of the HIV-1 epitopes defined by IFN $\gamma$ ELISpot analysis has been confirmed by IFN $\gamma$-specific ICS $(104,105)$. The CTL and TH epitopes on all HIV-1 proteins have been listed in Los Alamos National Laboratory (LANL) database (http://www.hiv. 
lanl.gov/content/immunology/maps/maps.html). Such database is useful in identifying the HIV-1 epitopes needed for developing prophylactic vaccines as well as immune-based therapy against HIV-1.

Perhaps the most problematic issue with the use of IFN $\gamma$-based analysis is that the IFN $\gamma$ levels from $\mathrm{CD}^{+}$and $\mathrm{CD}^{+}{ }^{+} \mathrm{T}$ cells alone do not correlate with HIV-1 load or disease progression (Table 3 ) $(78,79,83,105,107)$. For this reason, the HIV-specific IFN $\gamma$ levels only indicate the ability of these T cell subsets to produce IFN $\gamma$ responses to HIV-1 peptides. Polyfunctional T cells, which are involved in controlling HIV-1 load, express IFN $\gamma$ in addition to other cytokines and cytotoxins $(48,49,81-84)$ particularly in a combination of IFN $\gamma$ with perforin, IL-2, TNF $\alpha$, or granzyme B. These $\mathrm{T}$ cells are thought to be important in the control of HIV-1 infection in $\mathrm{HIV}^{+}$LTSs and ECs $(46,81,82)$. In addition, proliferative $\mathrm{T}$ cells expressing IFN $\gamma$ have also been observed at higher levels in LTS and EC, but at lower levels in $\mathrm{HIV}^{+}$progressors (46, 82 ). These studies suggest that vaccines that only induce IFN $\gamma$ in HIV-specific $\mathrm{CD}^{+}{ }^{+} \mathrm{T}$ cells and/or $\mathrm{CD} 8^{+} \mathrm{T}$ cells are unlikely to protect humans against HIV-1. Instead, those that induce polyfunctional $\mathrm{T}$ cell activities against HIV-1 are more likely to be useful as vaccine immunogens.

\section{IFN $\gamma$ IN PRECLINICAL VACCINE TRIALS}

Preclinical trials in the SIV/macaques model demonstrate the induction of SIV-specific polyfunctional $\mathrm{CD}^{+}{ }^{+}$and $\mathrm{CD} 8^{+} \mathrm{T}$ cell activity resulting in marked decreases in viral load using DNA or viral vector vaccine strategy as either post-infection therapy or prophylaxis against SIV (117-120). Epidermal co-delivery of SIV Gag, RT, Nef, and envelope (Env) DNA vaccine formulated with a mucosal genetic adjuvant induced a substantial decrease in peripheral and mucosal viral burden in chronically infected macaques (117). Durable and sustained suppression of viral load and nonprogression was positively associated with significant increases in SIV-specific IFN $\gamma$ responses in T cells from peripheral blood $(117,118)$ and gut mucosa (117). In addition, vaccination induced SIV-specific CD8 ${ }^{+}$T cells with dual TNF- $\alpha$ and cytolytic effector functions in peripheral blood (117). In vectored vaccine studies, rhesus cytomegalovirus vector expressing HIV-1 Gag, Pol, Nef, Env, RT, and integrase sequences demonstrated a high frequency of $\mathrm{CD} 69^{+} \mathrm{IFN}{ }^{+}$and/or $\mathrm{CD} 69^{+} \mathrm{TNF}^{+} \mathrm{CD} 4^{+}$and $\mathrm{CD}^{+}$effector memory $\mathrm{T}$ cell response that correlated to control of highly pathogenic $S_{\text {mac239 }}$ infection after mucosal challenge (119). The suppression of peak viral load and protection from challenge correlated with the magnitude of the peak SIV-specific $\mathrm{CD}^{+}{ }^{+} \mathrm{T}$ cell responses in the acute phase post-vaccination (described as the vaccine phase). Thirteen of the 24 vaccinated macaques had undetectable plasma viral loads that persisted up to 1 year (119). These responses have been demonstrated in distinct MHC-I and -II restricted $\mathrm{CD}^{+} \mathrm{T}$ cells, suggesting distinct patterns of epitope recognition in these $\mathrm{T}$ cell subsets (120). These studies outline the importance of the polyfunctional $\mathrm{T}$ cell responses in suppression of viral load in chronic infection and prevention of virus rebound after cessation of ART, and in the prophylaxis against AIDS viruses.

\section{IFN $\gamma$ AS A CYTOKINE ADJUVANT FOR HIV-1 VACCINE}

The use of IFN $\gamma$ as cytokine adjuvant for HIV-1 vaccines has been studied more extensively in animal models of AIDS than in humans. The rationale for using IFN $\gamma$ is based on its ability to promote CTL and NK cell activities as well as antibody production including induction of isotype switching $(6,42,43$, 121-124). Many cytokines, including those of IFN $\gamma$ and IFN $\gamma$ inducing cytokine (IL-12), have been used as a genetic-based cytokine adjuvant to enhance lentiviral DNA vaccines $(108,125)$. $\mathrm{SIV} /$ macaque and feline immunodeficiency virus (FIV)/cat AIDS models have been used extensively to determine the effect of cytokine as an adjuvant (Table 3) (108-111, 125). In one study, a vaccine consisting of SIV and IFN $\gamma$ DNA constructs was more effective against challenge with heterologous SIV than SIV DNA vaccine alone (109). However, a later SIV/macaque study was unable to confirm the results from the initial study (108). Furthermore, in FIV/cat model, laboratory cats vaccinated with FIV proviral deletion mutant $(\Delta$ vif or $\Delta \mathrm{RT})$ and IFN $\gamma$ DNA construct conferred either no protection $\left(\mathrm{FIV}_{\Delta \mathrm{vif}} / \mathrm{IFN} \gamma\right)$ or marginal

Table 3 | Interferon- $\gamma$ in development of an HIV-1 vaccine.

\section{Description}

Identifying vaccine epitopes

\section{Cytokine adjuvant $^{b}$}

Genetic IFN $\gamma$ adjuvant for DNA vaccine IFN $\gamma$ adjuvant for protein-based vaccine

No effect or some enhanced DNA vaccine efficacy in animal models No effect in an animal model
IFN $\gamma$ activity or immune response

Epitopes inducing only IFN $\gamma$ do not correlate with HIV load or disease progression
Reference

$(78,79,105,107)$
(108-111)

Pu and Yamamoto, unpublished observation

\section{Phase Ilb-III vaccine trials}

Phase III VaxGen 003 and 004 trials

Phase Ilb STEP trial

Phase III RV144 trial

\author{
IFN $\gamma$ responses by $\mathrm{CD}^{+} \mathrm{T}$ cells \\ (112) \\ (113) \\ (114) \\ (115) \\ (116)
}

a Evaluation in long-term survivors, elite controllers, and progressors.

${ }^{b}$ SIV/macaque model in genetic adjuvant and FIV/cat model in genetic and protein adjuvants. 
protection $\left(\mathrm{FIV}_{\Delta \mathrm{RT}} / \mathrm{IFN} \gamma\right)$ against heterologous FIV challenge when compared to cats vaccinated with FIV DNA construct alone $(110,111)$.

Cytokine adjuvant is more commonly used in DNA vaccines to enhance the low immune responses generated by the low viral antigen expression of the viral DNA $(126,127)$. Nevertheless, cytokineadjuvant studies have been performed with protein-based FIV vaccines containing conventional adjuvant. These studies show no (IFN $\gamma$ and IL-18) to moderate (IL-12 and -15) enhancement of protective activity of the viral immunogen or inactive whole-virus FIV when compared to those without cytokine (Table 3) (128, 129). In one study, laboratory cats immunized with inactivated FIV vaccine supplemented with IFN $\gamma$ in conventional adjuvant did not augment the protection observed with the vaccine without IFN $\gamma$ ( $\mathrm{Pu}$ and Yamamoto, unpublished observation). The inability of IFN $\gamma$ to enhance the vaccine efficacy may be attributed to the fact that AIDS lentiviral proteins themselves can induce IFN $\gamma$ production in $\mathrm{T}$ cells as observed in animals vaccinated with viral protein or inactivated virus in conventional adjuvant (128, 130133). Similarly, many of the HIV-1 proteins and peptides (core p24, enzyme RT, accessory Nef, and envelope gp120) can directly stimulate $\mathrm{T}$ cells from $\mathrm{HIV}^{+}$subjects or vaccinated HIV-negative subjects to produce IFN $\gamma(78,79,133-135)$. For these reasons, the use of IFN $\gamma$ as a cytokine adjuvant is unlikely to enhance the activities of an HIV-1 protein vaccine.

\section{IFN $\gamma$ IN PHASE IIb-III HIV-1 VACCINE TRIALS}

The last four major HIV-1 vaccine trials in humans consisted of two phase III vaccine trials using recombinant HIV-1 envelope gp120 protein of subtype B (VaxGen 004 trial) and subtypes $\mathrm{B}$ and E combined (VacGen 003) (135, 136); phase IIb STEP trial using adenovirus-5 vector (Ad5) expressing subtype-B HIV-1 gag/pol/nef (137); and phase III RV144 prime-boost trial consisting of canarypox vectored HIV-1 gag/pr/gp41-120 priming and boosting with subtypes B and E recombinant gp120 proteins (114, 115). More importantly, among the four trials only the primeboost RV144 trial had some efficacy. The RV144 trial had an efficacy of $31.2 \%$ in a general population but the efficacy of only $3.7 \%$ in the high risk group. In contrast, VaxGen gp120 trials had neither efficacy nor adverse effects $(135,136)$, while the STEP Ad5-vectored gag/pol/nef trial showed more HIV-1 infection in vaccinated subjects than placebo immunized subjects (137). All of the above vaccines induced HIV-specific IFN $\gamma$ responses from either $\mathrm{CD}^{+}{ }^{+}$or $\mathrm{CD}^{+}{ }^{+} \mathrm{T}$ cells and the duration of IFN $\gamma$ expression varied between the trials (Table 3$)(112,113,116,138)$.

In the initial report on $\mathrm{RV} 144$ trial, the $\mathrm{CD}^{+}{ }^{+}$and $\mathrm{CD} 8^{+} \mathrm{T}$ cells of the vaccinees were evaluated for IFN $\gamma$ ELISpot and IFN $\gamma /$ IL-2specific ICS responses to HIV-1 Gag and Env (115). Only IFN $\gamma / \mathrm{IL}-$ 2 -specific ICS to Env in the CD4 ${ }^{+}$T cells were significantly higher $(p<0.001)$ in the vaccinated group than in the placebo group (Table 3) (115). A more extensive immune-correlated analysis of RV144 trial demonstrated that the binding of IgG antibodies to variable regions 1 and 2 (V1, V2) of HIV-1 Env inversely correlated with the rate of HIV-1 infection ( $p=0.02$ ) (114). In contrast, the binding of plasma IgA antibodies to Env correlated positively with the rate of HIV-1 infection. Moreover, HIV-1 neutralizing antibodies, $\mathrm{T}$ cell responses, and specifically $\mathrm{T}$ cell produced IFN $\gamma$ responses that were detected in the vaccinees did not significantly affect the HIV-1 infection rate (114). A more extensive analysis of $T$ cell activity indicated that the prime-boost vaccination induced polyfunctional $\left(\mathrm{IFN} \gamma^{+}, \mathrm{IL}-2^{+}\right.$, and/or $\left.\mathrm{TNF}^{+}\right)$and potentially cytolytic (cytolytic marker CD107a ${ }^{+}$) $\mathrm{CD}^{+} \mathrm{T}$ cell responses to HIV-1 Env peptides, including the V2 peptides, 6 months after the last immunization (116). Thus, the most promising RV144 trial demonstrated the importance of IFN $\gamma$ in detecting polyfunctional T cells.

\section{CONCLUSION}

The difficulty in correlating serum IFN $\gamma$ levels with HIV/AIDS clinical status has been attributed to the role that IFN $\gamma$ plays as an inflammatory cytokine as well as a cytokine that enhances antiviral immunity. During the acute stage of HIV-1 infection, the host immune system mounts an inflammatory response resulting in a cytokine storm. In the cytokine storm, a number of inflammatory cytokines including IFN $\gamma$ are produced which decrease as the adaptive immune responses against HIV-1 develop. If not appropriately controlled, such inflammatory activities can enhance HIV1 infection and may cause a higher viral set point before $\mathrm{T}$ cell immunity can control the HIV-1 load. Remarkably, low levels of IFN $\gamma$ are detected throughout the course of HIV-1 infection correlating with persistently increasing HIV-1 load. Furthermore, many of the HIV-1 proteins can directly stimulate $\mathrm{T}$ cells from $\mathrm{HIV}^{+}$ subjects to produce IFN $\gamma$, leading to chronic immune activation and ultimately the exhaustion of the immune system and resulting in the loss of IFN $\gamma$ production.

Interferon- $\gamma$ therapy had no effect on HIV-1 load or AIDS progression whereas ART had a dramatic effect on both. However, long-term ART did not completely restore the immune responses in HIV-1 or completely eradicate the opportunistic infections. As a result, IFN $\gamma$ alone or in combination with other cytokines has successfully been used together with ART against HIV-associated opportunistic infections. Lastly, polyfunctional CD4 ${ }^{+} \mathrm{T}$ cells that expressed IFN $\gamma$ were observed in the vaccines of the most effective HIV-1 vaccine (RV144) trial to date. Hence, IFN $\gamma$ may still play an important role as a product of HIV-specific polyfunctional $\mathrm{CD} 4{ }^{+} \mathrm{T}$ cells which may serve to enhance the anti-HIV antibody production as well as CTLs against HIV-1.

\section{ACKNOWLEDGMENTS}

This work was supported by R01-AI30904 (Janet K. Yamamoto) and Janet K. Yamamoto Miscellaneous Donors Fund.

\section{REFERENCES}

1. Spellberg B, Edwards JE Jr. Type 1/type 2 immunity in infectious diseases. Clin Infect Dis (2001) 32(1):76-102. doi:10.1086/317537

2. Frucht DM, Fukao T, Bogdan C, Schindler H, O’Shea JJ, Koyasu S. IFN-gamma production by antigen-presenting cells: mechanisms emerge. Trends Immunol (2001) 22(10):556-60. doi:10.1016/S1471-4906(01)02005-1

3. Harris DP, Goodrich S, Gerth AJ, Peng SL, Lund FE. Regulation of IFN-gamma production by $\mathrm{B}$ effector 1 cells: essential roles for T-bet and the IFN-gamma receptor. J Immunol (2005) 174(11):6781-90.

4. Koirala J, Adamski A, Koch L, Stueber D, El-Azizi M, Khardori NM, et al. Interferon-gamma receptors in HIV-1 infection. AIDS Res Hum Retroviruses (2008) 24(8):1097-102. doi:10.1089/aid.2007.0261

5. Cobos Jiménez V, Booiman T, de Taeye SW, van Dort KA, Rits MA, Hamann J, et al. Differential expression of HIV-1 interfering factors in monocyte-derived 
macrophages stimulated with polarizing cytokines or interferons. Sci Rep (2012) 2:763. doi:10.1038/srep00763

6. Boehm U, Klamp T, Groot M, Howard JC. Cellular responses to interferongamma. Annu Rev Immunol (1997) 15:749-95. doi:10.1146/annurev.immunol. 15.1.749

7. Kumar SB, Rice CE, Milner DA Jr, Ramirez NC, Ackerman WE IV, Mwapasa $\mathrm{V}$, et al. Elevated cytokine and chemokine levels in the placenta are associated with in-utero HIV-1 mother-to-child transmission. AIDS (2012) 26:685-94. doi:10.1097/QAD.0b013e3283519b00

8. John-Stewart GC, Mbori-Ngacha D, Payne BL, Farquhar C, Richardson BA, Emery S, et al. HIV-1-specific cytotoxic T lymphocytes and breast milk HIV-1 transmission. J Infect Dis (2009) 199:889-98. doi:10.1086/597120

9. Lohman-Payne B, Slyker JA, Moore S, Maleche-Obimbo E, Wamalwa DC, Richardson BA, et al. Breast milk cellular HIV-specific interferon gamma responses are associated with peripartum HIV transmission. AIDS (2012) 26:2007-16. doi:10.1097/QAD.0b013e328359b7e0

10. Lohman BL, Slyker JA, Richardson BA, Farquhar C, Mabuka JM, Crudder C, et al. Longitudinal assessment of human immunodeficiency virus type 1 (HIV1)-specific gamma interferon responses during the first year of life in HIV-1infected infants. J Virol (2005) 79(13):8121-30. doi:10.1128/JVI.79.13.81218130.2005

11. Legrand FA, Nixon DF, Loo CP, Ono E, Chapman JM, Miyamoto M, et al. Strong HIV-1 specific T cell responses in HIV-1 exposed uninfected infants and neonates revealed after regulatory T cell removal. PLoS One (2006) 20(1):e102. doi:10.1371/journal.pone. 0000102

12. Kaul R, Rowland-Jones SL, Kimani J, Dong R, Yang H-B, Kiama P, et al. Late seroconversion in HIV-resistant Nairobi prostitutes despite pre-existing HIV-specific CD8+ responses. J Clin Invest (2001) 107(3):341-9. doi:10.1172/ JCI10714

13. Stacey AR, Norris PJ, Qin L, Haygreen EA, Taylor E, Heitman J, et al. Induction of a striking systemic cytokine cascade prior to peak viremia in acute human immunodeficiency virus type 1 infection, in contrast to more modest and delated responses in acute hepatitis B and C virus infections. J Virol (2009) 83:3719-33. doi:10.1128/JVI.01844-08

14. Cao J, McNevin J, Holte S, Fink L, Corey L, McElrath MJ. Comprehensive analysis of human immunodeficiency virus type 1 (HIV-1)-specific gamma interferon-secreting CD8+ T-cells in primary HIV-1 infection. J Virol (2003) 77:6867-78. doi:10.1128/JVI.77.12.6867-6878.2003

15. Dalod M, Dupuis M, Deschemin JC, Goujard C, Deveau C, Meyer L, et al. Weak anti-HIV CD8+ T-cell effector activity in HIV primary infection. J Clin Invest (1999) 104:1431-9. doi:10.1172/JCI7162

16. Lieberman J. Tracking the killers: how should we measure CD8 T cells in HIV infection? AIDS (2004) 18:1489-93. doi:10.1097/01.aids.0000131320.75396.4d

17. Zanussi S, D'Andrea MD, Simonelli C, Tirelli U, DePaoli P. Serum levels of RANTES and MIP- $1 \alpha$ in HIV-positive long-term survivors and progressor patients. AIDS (1996) 10:1431-2. doi:10.1097/00002030-199610000-00018

18. Harrer T, Harrer E, Kalams SA, Barbosa P, Trocha A, Johnson RP, et al. Cytotoxic T lymphocytes in asymptomatic long-term nonprogressing HIV-1 infection. Breadth and specificity of the response and relation to in vivo viral quasispecies in a person with prolonged infection and low viral load. J Immunol (1996) 156:2616-23.

19. Rinaldo C, Huang XL, Fan ZF, Ding M, Beltz L, Logar A, et al. High levels of anti-human immunodeficiency virus type-1 (HIV-1) memory cytotoxic Tlymphocyte activity and low viral load are associated with lack of disease in HIV-1 infected long-term nonprogressors. J Virol (1995) 69:5838-42.

20. Watanabe D, Uehira T, Yonemoto H, Bando H, Ogawa Y, Yajima K, et al. Sustained high levels of serum interferon-gamma during HIV-1 infection: a specific trend different from other cytokines. Viral Immunol (2010) 23(6):619-25. doi:10.1089/vim.2010.0065

21. Naranbhai V, Abdool Karim SS, Altfeld M, Samsunder N, Durgiah R, Sibeko $S$, et al. Innate immune activation enhances HIV acquisition in women, diminishing the effectiveness of tenofovir microbicide gel. J Infect Dis (2012) 206(7):993-1001. doi:10.1093/infdis/iis465

22. Lieberman J, Shankar P, Manjunath N, Andersson J. Dressed to kill? A review of why antiviral CD8 $\mathrm{T}$ lymphocytes fail to prevent progressive immunodeficiency in HIV-1 infection. Blood (2001) 98:1667-77. doi:10.1182/blood.V98.6.1667
23. Roberts L, Passmore JA, Williamson C, Little F, Bebell LM, Mlisana K, et al. Plasma cytokine levels during acute HIV-1 infection predict HIV disease progression. AIDS (2010) 24:819-31. doi:10.1097/QAD.0b013e3283367836

24. Isaacs A, Lindermann J. Virus interference. I. The interferon. Proc $R$ Soc Lond B Biol Sci (1957) 147:258-67. doi:10.1098/rspb.1957.0048

25. Samuel CE. Antiviral actions of interferons. Clin Microbiol Rev (2001) 14(4):778-809. doi:10.1128/CMR.14.4.778-809.2001

26. Schroeder J, Hertzog PJ, Ravasi T, Hume DA. Interferon- $\gamma$ : an overview of signals, mechanisms and functions. J Leukoc Biol (2004) 75:163-89. doi:10.1189/ jlb.0603252

27. Polyak MJ, Vivithanaporn P, Maingat FG, Walsh JG, Branton W, Cohen EA, et al. Differential type 1 interferon-regulated gene expression in the brain during AIDS: interactions with viral diversity and neurovirulence. FASEB J (2013) 27(7):2829-44. doi:10.1096/fj.13-227868

28. Tokarev A, Skasko M, Fitzpatrick K, Guatelli J. Antiviral activity of the interferon-induced cellular protein BST-2/tetherin. AIDS Res Hum Retroviruses (2009) 25(12):1197-210. doi:10.1089/aid.2009.0253

29. Simm M. The innate cellular responses to HIV-1 invasion: emerging molecules of ancient-defense mechanisms. Arch Immunol Ther Exp (Warsz) (2007) 55(3):131-8. doi:10.1007/s00005-007-0023-9

30. Bitzegeio J, Sampias M, Bieniasz PD, Hatziioannou T. Adaptation to the interferon-induced antiviral state by human and simian immunodeficiency viruses. J Virol (2013) 87(6):3549-60. doi:10.1128/JVI.03219-12

31. Yamamoto JK, Barré-Sinoussi F, Bolton V, Pedersen NC, Gardner MB. Human alpha- and beta-interferon but not gamma-suppress the in vitro replication of LAV, HTLV-III, and ARV-2. J Interferon Res (1986) 6(2):143-52. doi:10.1089/jir.1986.6.143

32. Kirchner $\mathrm{H}$. The interferon system as an integral part of the defense system against infections. Antiviral Res (1986) 6(1):1-17. doi:10.1016/0166-3542(86) 90035-5

33. Mackewicz CE, Ortega H, Levy JA. Effect of cytokines on HIV replication in CD4+ lymphocytes: lack of identity with the CD8+ cell antiviral factor. Cell Immunol (1994) 153(2):329-43. doi:10.1006/cimm.1994.1032

34. Matsuyama T, Kobayashi N, Yamamoto N. Cytokines and HIV infection: is AIDS a tumor necrosis factor disease? AIDS (1991) 5(12):1405-17. doi:10. 1097/00002030-199112000-00001

35. Levy JA, editor. Effect of HIV on various tissues and organ systems in the host. 3rd ed. Chap. 5. HIV and the Pathogenesis of AIDS. Washington DC: ASM Press (2007). p. 165-207.

36. Borrow P, Lewicki H, Hahn BH, Shaw GM, Oldstone MB. Virus-specific CD8+ cytotoxic T-lymphocyte activity associated with control of viremia in primary human immunodeficiency virus type 1 infection. J Virol (1994) 68(9): 6103-10.

37. Yang OO, Daar ES, Ng HL, Shih R, Jamieson BD. Increasing CTL targeting of conserved sequences during early HIV-1 infection is correlated to decreasing viremia. AIDS Res Hum Retroviruses (2011) 27(4):391-8. doi:10.1089/aid. 2010.0183

38. Leeansyah E, Malone DF, Anthony DD, Sandberg JK. Soluble biomarkers of HIV transmission, disease progression and comorbidities. Curr Opin HIV AIDS (2013) 8(2):117-24. doi:10.1097/COH.0b013e32835c7134

39. Katsikis PD, Mueller YM, Villinger F. The cytokine network of acute HIV infection: a promising target for vaccines and therapy to reduce viral set-point? PLoS Pathog (2011) 7(8):e1002055. doi:10.1371/journal.ppat.1002055

40. Sterling TR, Vlahov D, Astemborski J, Hoover DR, Margolick JB, Quinn TC. Initial plasma HIV-1 RNA levels and progression to AIDS in women and men. N Engl J Med (2001) 344(10):720-5. doi:10.1056/NEJM200103083441003

41. Lavreys L, Baeten JM, Chohan V, McClelland RS, Hassan WM, Richardson BA, et al. Higher set point plasma viral load and more-severe acute HIV type 1 (HIV-1) illness predict mortality among high-risk HIV-1-infected African women. Clin Infect Dis (2006) 42(9):1333-9. doi:10.1086/503258

42. Gromo G, Geller RL, Inverardi L, Bach FH. Signal requirements in the step-wise functional maturation of cytotoxic T lymphocytes. Nature (1987) 327(6121):424-6. doi:10.1038/327424a0

43. Maraskovsky E, Chen WF, Shortman K. IL-2 and IFN-gamma are two necessary lymphokines in the development of cytolytic T cells. J Immunol (1989) 143(4):1210-4. 
44. Soghoian DZ, Jessen H, Flanders M, Sierra-Davidson K, Cutler S, Pertel $\mathrm{T}$, et al. HIV-specific cytolytic CD4 $\mathrm{T}$ cell responses during acute HIV infection predict disease outcome. Sci Transl Med (2012) 4(123):123ra25. doi:10.1126/scitranslmed.3003165

45. Betts MR, Krowka JF, Kepler TB, Davidian M, Christopherson C, Kwok S, et al. Human immunodeficiency virus type 1-specific cytotoxic T lymphocyte activity is inversely correlated with HIV type 1 viral load in HIV type 1-infected long-term survivors. AIDS Res Hum Retroviruses (1999) 15(13):1219-28. doi: $10.1089 / 088922299310313$

46. Blankson JN. Effector mechanisms in HIV-1 infected elite controllers: highly active immune responses? Antiviral Res (2010) 85(1):295-302. doi:10.1016/j. antiviral.2009.08.007

47. Deeks SG, Walker BD. Human immunodeficiency virus controllers: mechanisms of durable virus control in the absence of antiretroviral therapy. Immunity (2007) 27(3):406-16. doi:10.1016/j.immuni.2007.08.010

48. McNicholl JM, Promadej N. Insights into the role of host genetic and T-cell factors in resistance to HIV transmission from studies of highly HIV-exposed Thais. Immunol Res (2004) 29(1-3):161-74. doi:10.1385/IR:29:1-3:161

49. Agosti JM, Coombs RW, Collier AC, Paradise MA, Benedetti JK, Jaffe HS, et al. A randomized, double-blind, phase I/II trial of tumor necrosis factor and interferon-gamma for treatment of AIDS-related complex (Protocol 025 from the AIDS Clinical Trials Group). AIDS Res Hum Retroviruses (1992) 8(5):581-7. doi:10.1089/aid.1992.8.581

50. Kaplan LD, Abrams DI, Sherwin SA, Kahn J, Volberding PA. A phase I/II study of recombinant tumor necrosis factor and recombinant interferon gamma in patients with AIDS-related complex. Biotechnol Ther (1989-1990) 1(3):229-36.

51. Lane HC, Davey RT Jr, Sherwin SA, Masur H, Rook AH, Manischewitz JF, et al. A phase I trial of recombinant human interferon-gamma in patients with Kaposi's sarcoma and the acquired immunodeficiency syndrome (AIDS). JClin Immunol (1989) 9(4):351-61. doi:10.1007/BF00918667

52. Heagy W, Groopman J, Schindler J, Finberg R. Use of IFN-gamma in patients with AIDS. J Acquir Immune Defic Syndr (1990) 3(6):584-90.

53. Krown SE. Interferon-alpha: evolving therapy for AIDS-associated Kaposi's sarcoma. J Interferon Cytokine Res (1998) 18(4):209-14. doi:10.1089/jir.1998. 18.209

54. Krown SE. Interferon and other biologic agents for the treatment of Kaposi's sarcoma. Hematol Oncol Clin North Am (1991) 5(2):311-22.

55. Shearer WT, Kline MW, Abramson SL, Fenton T, Starr SE, Douglas SD. Recombinant human gamma interferon in human immunodeficiency virus-infected children: safety, CD4(+)-lymphocyte count, viral load, and neutrophil function (AIDS Clinical Trials Group Protocol 211). Clin Diagn Lab Immunol (1999) 6(3):311-5.

56. Valdez H, Lederman MM. Cytokines and cytokine therapies in HIV infection. AIDS Clin Rev (1997)1997-1998:187-228.

57. Poli G, Biswas P, Fauci AS. Interferons in the pathogenesis and treatment of human immunodeficiency virus infection. Antiviral Res (1994) 24 (2-3):221-33. doi:10.1016/0166-3542(94)90069-8

58. Asmuth DM, Murphy RL, Rosenkranz SL, Lertora JJ, Kottilil S, Cramer Y, et al. AIDS Clinical Trials Group A5192 Team. Safety, tolerability, and mechanisms of antiretroviral activity of pegylated interferon Alfa-2a in HIV-1 monoinfected participants: a phase II clinical trial. J Infect Dis (2010) 201(11):1686-96. doi:10.1086/652420

59. Aldenhoven M, Barlo NP, Sanders CJ. Therapeutic strategies for epidemic Kaposi's sarcoma. Int J STD AIDS (2006) 17(9):571-8. doi:10.1258/ 095646206778113131

60. Aversa SM, Cattelan AM, Salvagno L, Crivellari G, Banna G, Trevenzoli M, et al. Treatments of AIDS-related Kaposi's sarcoma. Crit Rev Oncol Hematol (2005) 53(3):253-65. doi:10.1016/j.critrevonc.2004.10.009

61. Pappas PG, Bustamante B, Ticona E, Hamill RJ, Johnson PC, Reboli A, et al. Recombinant interferon-gamma $1 b$ as adjunctive therapy for AIDSrelated acute cryptococcal meningitis. J Infect Dis (2004) 189(12):2185-91. doi:10.1086/420829

62. Jarvis JN, Meintjes G, Rebe K, Williams GN, Bicanic T, Williams A, et al. Adjunctive interferon- $\gamma$ immunotherapy for the treatment of HIV-associated cryptococcal meningitis: a randomized controlled trial. AIDS (2012) 26(9):1105-13. doi:10.1097/QAD.0b013e3283536a93
63. Gamaletsou MN, Sipsas NV, Kontoyiannis DP, Tsiakalos A, Kontos AN, Stefanou I, et al. Successful salvage therapy of refractory HIV-related cryptococcal meningitis with the combination of liposomal amphotericin B, voriconazole, and recombinant interferon- $\gamma$. Diagn Microbiol Infect Dis (2012) 74(4):409-11. doi:10.1016/j.diagmicrobio.2012.08.009

64. Riddell LA, Pinching AJ, Hill S, Ng TT, Arbe E, Lapham GP, et al. A phase III study of recombinant human interferon gamma to prevent opportunistic infections in advanced HIV disease. AIDS Res Hum Retroviruses (2001) 17(9):789-97. doi:10.1089/088922201750251981

65. Kedzierska K, Azzam R, Ellery P, Mak J, Jaworowski A, Crowe SM. Defective phagocytosis by human monocyte/macrophages following HIV-1 infection: underlying mechanisms and modulation by adjunctive cytokine therapy. J Clin Virol (2003) 26(2):247-63. doi:10.1016/S1386-6532(02)00123-3

66. Squires KE, Brown ST, Armstrong D, Murphy WF, Murray HW. Interferongamma treatment for Mycobacterium avium-intracellular complex bacillemia in patients with AIDS. J Infect Dis (1992) 166(3):686-7. doi:10.1093/infdis/ 166.3.686

67. Murray HW. Current and future clinical applications of interferon-gamma in host antimicrobial defense. Intensive Care Med (1996) 22(Suppl 4):S456-61. doi:10.1007/BF01743724

68. Gasser O, Brander C, Wolbers M, Brown NV, Rauch A, Günthard HF, et al. Cohort Study. Expansion of interferon- $\gamma$-secreting HIV-specific T cells during successful antiretroviral therapy. HIV Med (2013) 14(4):241-6. doi:10.1111/j. 1468-1293.2012.01040.x

69. Harari A, Petitpierre S, Vallelian F, Pantaleo G. Skewed representation of functionally distinct populations of virus-specific CD4 T cells in HIV-1-infected subjects with progressive disease: changes after antiretroviral therapy. Blood (2004) 103(3):966-72. doi:10.1182/blood-2003-04-1203

70. Trabattoni D, Piconi S, Biasin M, Rizzardini G, Migliorino M, Seminari E, et al. Granule-dependent mechanisms of lysis are defective in CD8 T cells of HIVinfected, antiretroviral therapy-treated individuals. AIDS (2004) 18(6):859-69. doi:10.1097/00002030-200404090-00003

71. Casazza JP, Betts MR, Picker LJ, Koup RA. Decay kinetics of human immunodeficiency virus-specific CD8+ $\mathrm{T}$ cells in peripheral blood after initiation of highly active antiretroviral therapy. J Virol (2001) 75(14):6508-16. doi:10.1128/JVI.75.14.6508-6516.2001

72. Orsilles MA, Pieri E, Cooke P, Caula C. IL-2 and IL-10 serum levels in HIV-1infected patients with or without active antiretroviral therapy. APMIS (2006) 114(1):55-60. doi:10.1111/j.1600-0463.2006.apm_108.x

73. Stylianou E, Aukrust P, Kvale D, Müller F, Frøland SS. IL-10 in HIV infection: increasing serum IL-10 levels with disease progression - down-regulatory effect of potent anti-retroviral therapy. Clin Exp Immunol (1999) 116(1): 115-20.

74. Stylianou E, Bjerkeli V, Yndestad A, Heggelund L, Waehre T, Damås JK, et al. Raised serum levels of interleukin-18 is associated with disease progression and may contribute to virological treatment failure in HIV-1-infected patients. Clin Exp Immunol (2003) 132(3):462-6. doi:10.1046/j.1365-2249.2003.02179.x

75. Torre D, Speranza F, Martegani R, Pugliese A, Castelli F, Basilico C, et al. Circulating levels of IL-18 in adult and paediatric patients with HIV-1 infection. AIDS (2000) 14(14):2211-2. doi:10.1097/00002030-200009290-00023

76. Iannello A, Tremblay C, Routy JP, Boulassel MR, Toma E, Ahmad A. Decreased levels of circulating IL-21 in HIV-infected AIDS patients: correlation with CD4+ T-cell counts. Viral Immunol (2008) 21(3):385-8. doi:10.1089/vim.2008. 0025

77. Iannello A, Boulassel MR, Samarani S, Debbeche O, Tremblay C, Toma E, et al. Dynamics and consequences of IL-21 production in HIV-infected individuals: a longitudinal and cross-sectional study. J Immunol (2010) 184(1):114-26. doi:10.4049/jimmunol.0901967

78. Streeck H, Frahm N, Walker BD. The role of IFN-gamma Elispot assay in HIV vaccine research. Nat Protoc (2009) 4(4):461-9. doi:10.1038/nprot.2009.7

79. Addo MM, Yu XG, Rathod A, Cohen D, Eldridge RL, Strick D, et al. Comprehensive epitope analysis of human immunodeficiency virus type 1 (HIV-1)specific T-cell responses directed against the entire expressed HIV-1 genome demonstrate broadly directed responses, but no correlation to viral load. J Virol (2003) 77(3):2081-92. doi:10.1128/JVI.77.3.2081-2092.2003

80. Streeck H, Nixon DF. T cell immunity in acute HIV-1 infection. J Infect Dis (2010) 202(Suppl 2):S302-8. doi:10.1086/655652 
81. Boaz MJ, Waters A, Murad S, Easterbrook PJ, Vyakarnam A. Presence of HIV1 Gag-specific IFN-gamma+IL-2+ and CD28+IL-2+ CD4 T cell responses is associated with nonprogression in HIV-1 infection. J Immunol (2002) 169(11):6376-85.

82. Boaz MJ, Waters A, Murad S, Easterbrook PJ, D'Sousa E, van Wheeley C, et al. CD4 responses to conserved HIV-1 T helper epitopes show both negative and positive associations with virus load in chronically infected subjects. Clin Exp Immunol (2003) 134(3):454-63. doi:10.1111/j.1365-2249.2003.02307.x

83. Richmond M, McKinnon LR, Kiazyk SA, Wachihi C, Kimani M, Kimani J, et al. Epitope mapping of HIV-specific CD8+ T cell responses by multiple immunological readouts reveals distinct specificities defined by function. J Virol (2011) 85(3):1275-86. doi:10.1128/JVI.01707-10

84. Zanussi S, Simonelli C, D’Andrea M, Caffau C, Clerici M, Tirelli U, et al. CD8+ lymphocyte phenotype and cytokine production in long-term non-progressor and in progressor patients with HIV-1 infection. Clin Exp Immunol (1996) 105(2):220-4.

85. Rehr M, Cahenzli J, Haas A, Price DA, Gostick E, Huber M, et al. Emergence of polyfunctional CD8+ T cells after prolonged suppression of human immunodeficiency virus replication by antiretroviral therapy. J Virol (2008) 82(7):3391-404. doi:10.1128/JVI.02383-07

86. McQuillan GM, Kruszon-Moran D, Kottiri BJ, Kamimoto LA, Lam L, Cowart MF, et al. Prevalence of HIV in the US household population: the National Health and Nutrition Examination Surveys, 1988 to 2002. J Acquir Immune Defic Syndr (2006) 41(5):651-6. doi:10.1097/01.qai.0000194235.31078.f6

87. World Health Organization (WHO). Towards Universal Access: Scaling Up Priority HIV/AIDS Interventions in the Health Sector. Progress report (2009). Available from: http://www.who.int/hiv/pub/2009progressreport/en

88. Boyd MA, Hill AM. Clinical management of treatment-experienced, HIV/AIDS patients in the combination antiretroviral therapy era. Pharmacoeconomics (2010) 28(Suppl 1):17-34. doi:10.2165/11587420-000000000-00000

89. Zolopa AR. The evolution of HIV treatment guidelines: current state-ofthe-art of ART. Antiviral Res (2010) 85(1):241-4. doi:10.1016/j.antiviral.2009. 10.018

90. Guihot A, Tubiana R, Breton G, Marcelin AG, Samri A, Assoumou L, et al. Immune and virological benefits of 10 years of permanent viral control with antiretroviral therapy. AIDS (2010) 24(4):614-7. doi:10.1097/QAD. 0b013e32833556f3

91. Lok JJ, Bosch RJ, Benson CA, Collier AC, Robbins GK, Shafer RW, et al. Long-term increase in CD4+ T-cell counts during combination antiretroviral therapy for HIV-1 infection. AIDS (2010) 24(12):1867-76. doi:10.1097/QAD. 0b013e32833adbcf

92. Gupta A, Wood R, Kaplan R, Bekker LG, Lawn SD. Tuberculosis incidence rates during 8 years of follow-up of an antiretroviral treatment cohort in South Africa: comparison with rates in the community. PLoS One (2012) 7(3):e34156. doi:10.1371/journal.pone.0034156

93. Markowitz N, Lopardo G, Wentworth D, Gey D, Babiker A, Fox L, et al. Long-term effects of intermittent IL-2 in HIV infection: extended followup of the INSIGHT STALWART Study. PLoS One (2012) 7(10):e47506. doi:10.1371/journal.pone.0047506

94. Sternfeld T, Nigg A, Belohradsky BH, Bogner JR. Treatment of relapsing Mycobacterium avium infection with interferon-gamma and interleukin-2 in an HIV-negative patient with low CD4 syndrome. Int J Infect Dis (2010) 14(Suppl 3):198-201. doi:10.1016/j.ijid.2009.08.004

95. Abzug MJ, Walsh TJ. Interferon-gamma and colony-stimulating factors as adjuvant therapy for refractory fungal infections in children. Pediatr Infect Dis J (2004) 23(8):769-73. doi:10.1097/01.inf.0000134314.65398.bf

96. Naidoo K, Yende-Zuma N, Padayatchi N, Naidoo K, Jithoo N, Nair G, et al. The immune reconstitution inflammatory syndrome after antiretroviral therapy initiation in patients with tuberculosis: findings from the SAPiT trial. Ann Intern Med (2012) 157(5):313-24. doi:10.7326/0003-4819-157-5-20120904000004

97. Corey DM, Kim HW, Salazar R, Illescas R, Villena J, Gutierrez L, et al. Brief report: effectiveness of combination antiretroviral therapy on survival and opportunistic infections in a developing world setting: an observational cohort study. J Acquir Immune Defic Syndr (2007) 44(4):451-5. doi:10.1097/QAI. ob013e31802f8512

98. Koenig SP, Rodriguez LA, Bartholomew C, Edwards A, Carmichael TE, Barrow $\mathrm{G}$, et al. Long-term antiretroviral treatment outcomes in seven countries in the Caribbean. J Acquir Immune Defic Syndr (2012) 59(4):60-71. doi:10.1097/ QAI.0b013e318245d3c1

99. Armstrong WS. The immune reconstitution inflammatory syndrome: a clinical update. Curr Infect Dis Rep (2013) 15(1):39-45. doi:10.1007/s11908-0120308-y

100. Rasul S, Delapenha R, Farhat F, Gajjala J, Zahra SM. Graves' disease as a manifestation of immune reconstitution in HIV-infected individuals after initiation of highly active antiretroviral therapy. AIDS Res Treat (2011) 2011:743597. doi:10.1155/2011/743597

101. Sharma SK, Soneja M. HIV \& immune reconstitution inflammatory syndrome (IRIS). Indian J Med Res (2011) 134(6):866-77. doi:10.4103/0971-5916.92632

102. Wiesner DL, Boulware DR. Cryptococcus-related immune reconstitution inflammatory syndrome (IRIS): pathogenesis and its clinical implications. Curr Fungal Infect Rep (2011) 5(4):252-61. doi:10.1007/s12281-011-0064-8

103. Grant PM, Komarow L, Lederman MM, Pahwa S, Zolopa AR, Andersen J, et al. Elevated interleukin 8 and T-helper 1 and T-helper 17 cytokine levels prior to antiretroviral therapy in participants who developed immune reconstitution inflammatory syndrome during ACTG A5164. J Infect Dis (2012) 206(11):1715-23. doi:10.1093/infdis/jis604

104. Harari A, Bart PA, Stöhr W, Tapia G, Garcia M, Medjitna-Rais E, et al. An HIV1 clade C DNA prime, NYVAC boost vaccine regimen induces reliable, polyfunctional, and long-lasting T cell responses. J Exp Med (2008) 205(1):63-77. doi:10.1084/jem.20071331

105. Draenert R, Altfeld M, Brander C, Basgoz N, Corcoran C, Wurcel AG, et al. Comparison of overlapping peptide sets for detection of antiviral CD8 and CD4 T cell responses. J Immunol Methods (2003) 275(1-2):19-29. doi:10.1016/ S0022-1759(02)00541-0

106. Baier-Bitterlich G, Fuchs D, Wachter H. Chronic immune stimulation, oxidative stress, and apoptosis in HIV infection. Biochem Pharmacol (1997) 53(6):755-63. doi:10.1016/S0006-2952(96)00651-X

107. Yang OO. Will we be able to "spot" an effective HIV-1 vaccine? Trends Immunol (2003) 24(2):67-72. doi:10.1016/S1471-4906(02)00034-0

108. Lena P, Villinger F, Giavedoni L, Miller CJ, Rhodes G, Luciw P. Coimmunization of rhesus macaques with plasmid vectors expressing IFNgamma, GM-CSF, and SIV antigens enhances anti-viral humoral immunity but does not affect viremia after challenge with highly pathogenic virus. Vaccine (2002) 20(Suppl 4):A69-79. doi:10.1016/S0264-410X(02)00391-2

109. Giavedoni L, Ahmad S, Jones L, Yilma T. Expression of gamma interferon by simian immunodeficiency virus increases attenuation and reduces postchallenge virus load in vaccinated rhesus macaques. J Virol (1997) 71(2):866-72.

110. Hosie MJ, Flynn JN, Rigby MA, Cannon C, Dunsford T, Mackay NA, et al. DNA vaccination affords significant protection against feline immunodeficiency virus infection without inducing detectable antiviral antibodies. J Virol (1998) 72(9):7310-9.

111. Gupta S, Leutenegger CM, Dean GA, Steckbeck JD, Cole KS, Sparger EE. Vaccination of cats with attenuated feline immunodeficiency virus proviral DNA vaccine expressing gamma interferon. J Virol (2007) 81(2):465-73. doi:10.1128/JVI.00815-06

112. Jones NG, DeCamp A, Gilbert P, Peterson ML, Gurwith M, Cao H. AIDSVAX immunization induces HIV-specific CD8+ T-cell responses in high-risk, HIVnegative volunteers who subsequently acquire HIV infection. Vaccine (2009) 27(7):1136-40. doi:10.1016/j.vaccine.2008.11.071

113. Li F, Finnefrock AC, Dubey SA, Korber BT, Szinger J, Cole S, et al. Mapping HIV-1 vaccine induced T-cell responses: bias towards less-conserved regions and potential impact on vaccine efficacy in the Step study. PLoS One (2011) 6:e20479. doi:10.1371/journal.pone.0020479

114. de Souza MS, Ratto-Kim S, Chuenarom W, Schuetz A, Chantakulkij S, Nuntapinit B, et al. The Thai phase III trial (RV144) vaccine regimen induces $\mathrm{T}$ cell responses that preferentially target epitopes within the V2 region of HIV-1 envelope. J Immunol (2012) 188(10):5166-76. doi:10.4049/jimmunol.1102756

115. Rerks-Ngarm S, Pitisuttithum P, Nitayaphan S, Kaewkungwal J, Chiu J, Paris $\mathrm{R}$, et al. Vaccination with ALVAC and AIDSVAX to prevent HIV-1 infection in Thailand. NEngl JMed (2009) 361(23):2209-20. doi:10.1056/NEJMoa0908492

116. Haynes BF, Gilbert PB, McElrath MJ, Zolla-Pazner S, Tomaras GD, Alam $\mathrm{SM}$, et al. Immune-correlates analysis of an HIV-1 vaccine efficacy trial. N Engl J Med (2012) 366(14):1275-86. doi:10.1056/NEJMoa1113425

117. Fuller DH, Rajakumar P, Che JW, Narendran A, Nyaundi J, Michael H, et al. Therapeutic DNA vaccine induces broad $\mathrm{T}$ cell responses in the gut and 
sustained protection from viral rebound and AIDS in SIV-infected rhesus macaques. PLoS One (2012) 87(3):e33715. doi:10.1371/journal.pone.0033715

118. von Gegerfelt AS, Rosati M, Alicea C, Valentin A, Roth P, Bear J, et al. Longlasting decrease in viremia in macaques chronically infected with simian immunodeficiency virus SIVmac251 after therapeutic DNA immunization. J Virol (2007) 81(4):1972-9. doi:10.1128/JVI.01990-06

119. Hansen SG, Ford JC, Lewis MS, Ventura AB, Colette M, Hughes CM, et al. Profound early control of highly pathogenic SIV by an effector-memory T cell vaccine. Nature (2011) 473(7348):523-7. doi:10.1038/nature10003

120. Hansen SG, Sacha JB, Hughes CM, Ford JC, Burwitz B, Scholz I, et al. Cytomegalovirus vectors violate $\mathrm{CD} 8+\mathrm{T}$ cell epitope recognition paradigms. Science (2013) 340(6135):1237874. doi:10.1126/science.1237874

121. Blackman MJ, Morris AG. The effect of interferon treatment of targets on susceptibility to cytotoxic T-lymphocyte killing: augmentation of allogeneic killing and virus-specific killing relative to viral antigen expression. Immunology (1985) 56(3):451-7.

122. Mills FC, Brooker JS, Camerini-Otero RD. Sequences of human immunoglobulin switch regions: implications for recombination and transcription. Nucleic Acids Res (1990) 18(24):7305-16. doi:10.1093/nar/18.24.7305

123. Welsh RM. Natural killer cells and interferon. Crit Rev Immunol (1984) 5(1):55-93.

124. Senik A, Stefanos S, Kolb JP, Lucero M, Falcoff E. Enhancement of mouse natural killer cell activity by type II interferon. Ann Immunol (Paris) (1980) 131c:349-61.

125. Halwani R, Boyer JD, Yassine-Diab B, Haddad EK, Robinson TM, Kumar S, et al. Therapeutic vaccination with simian immunodeficiency virus (SIV)-DNA + IL-12 or IL-15 induces distinct CD8 memory subsets in SIV-infected macaques. J Immunol (2008) 180(12):7969-79.

126. Muthumani K, Kudchodkar S, Zhang D, Bagarazzi ML, Kim JJ, Boyer JD, et al. Issues for improving multiplasmid DNA vaccines for HIV-1. Vaccine (2002) 20(15):1999-2003. doi:10.1016/S0264-410X(02)00086-5

127. Abdulhaqq SA, Weiner DB. DNA vaccines: developing new strategies to enhance immune responses. Immunol Res (2008) 42(1-3):219-32. doi:10.1007/ s12026-008-8076-3

128. Coleman JK, Pu R, Martin M, Sato E, Yamamoto JK. HIV-1 p24 vaccine protects cats against feline immunodeficiency virus infection. AIDS (2005) 19(14):1457-66. doi:10.1097/01.aids.0000183627.81922.be

129. Coleman JK, Pu P, Martin MM, Noon-Song EN, Zwijnenberg R, Yamamoto JK. Feline immunodeficiency virus (FIV) vaccine and neutralizing antibodies against heterologous FIV subtype strains. Vaccine (2013). doi:10.1016/j. vaccine.2013.05.024

130. Abbott JR, Pu R, Coleman JK, Yamamoto JK. Utilization of feline ELISPOT for mapping vaccine epitopes. Methods Mol Biol (2012) 792:47-63. doi:10.1007/ 978-1-61779-325-7_4

131. Uhl EW, Martin M, Coleman JK, Yamamoto JK. Advances in FIV vaccine technology. Vet Immunol Immunopath (2008) 123:65-80. doi:10.1016/j.vetimm. 2008.01.030
132. Van Braeckel E, Bourguignon P, Koutsoukos M, Clement F, Janssens M, Carletti I, et al. An adjuvanted polyprotein HIV-1 vaccine induces polyfunctional cross-reactive CD4+ T cell responses in seronegative volunteers. Clin Infect Dis (2011) 52(4):522-31. doi:10.1093/cid/ciq160

133. Mortara L, Gras-Masse H, Rommens C, Venet A, Guillet JG, Bourgault-Villada I. Type $1 \mathrm{CD} 4(+)$ T-cell help is required for induction of antipeptide multispecific cytotoxic $\mathrm{T}$ lymphocytes by a lipopeptidic vaccine in rhesus macaques. J Virol (1999) 73(5):4447-51.

134. Evans TG, Fitzgerald T, Gibbons DC, Keefer MC, Soucier H. Th1/Th2 cytokine responses following HIV-1 immunization in seronegative volunteers. The AIDS Vaccine Evaluation Group. Clin Exp Immunol (1998) 111(2):243-50.

135. Flynn NM, Forthal DN, Harro CD, Judson FN, Mayer KH, Para MF, et al. Placebo-controlled phase 3 trial of a recombinant glycoprotein 120 vaccine to prevent HIV-1 infection. J Infect Dis (2005) 191(5):654-65. doi:10.1086/ 428404

136. Pitisuttithum P, Gilbert P, Gurwith M, Heyward W, Martin M, van Griensven F, et al. Randomized, double-blind, placebo-controlled efficacy trial of a bivalent recombinant glycoprotein $120 \mathrm{HIV}-1$ vaccine among injection drug users in Bangkok, Thailand. J Infect Dis (2006) 194(12):1661-71. doi:10.1086/ 508748

137. Buchbinder SP, Mehrotra DV, Duerr A, Fitzgerald DW, Mogg R, Li D, et al. Efficacy assessment of a cell-mediated immunity HIV-1 vaccine (the Step Study): a double-blind, randomised, placebo-controlled, test-of-concept trial. Lancet (2008) 372(9653):1881-93. doi:10.1016/S0140-6736(08)61591-3

138. McElrath MJ, De Rosa SC, Moodie Z, Dubey S, Kierstead L, Janes H, et al. HIV-1 vaccine-induced immunity in the test-of-concept Step Study: a case-cohort analysis. Lancet (2008) 372(9653):1894-905. doi:10.1016/S01406736(08)61592-5

Conflict of Interest Statement: The authors declare that the research was conducted in the absence of any commercial or financial relationships that could be construed as a potential conflict of interest.

Received: 18 October 2013; accepted: 17 December 2013; published online: 13 January 2014.

Citation: Roff SR, Noon-Song EN and Yamamoto JK (2014) The significance of interferon- $\gamma$ in HIV-1 pathogenesis, therapy, and prophylaxis. Front. Immunol. 4:498. doi: $10.3389 /$ fimmu.2013.00498

This article was submitted to Immunotherapies and Vaccines, a section of the journal Frontiers in Immunology.

Copyright (c) 2014 Roff, Noon-Song and Yamamoto. This is an open-access article distributed under the terms of the Creative Commons Attribution License (CC BY). The use, distribution or reproduction in other forums is permitted, provided the original author(s) or licensor are credited and that the original publication in this journal is cited, in accordance with accepted academic practice. No use, distribution or reproduction is permitted which does not comply with these terms. 